\title{
Beyond consent: the potential for atrocity
}

\author{
Allan Gaw
}

J R Soc Med 2006;99:175-177

With disbelief the world received news of medical experiments performed on the inmates of concentration camps in Nazi Germany. ${ }^{1}$ The subsequent trial of 23 defendants, 20 of whom were medically qualified, in Nuremberg yielded 16 guilty verdicts and seven death sentences. What was perhaps so incredulous was not that such atrocities could be perpetrated by Nazis, but that they could have involved doctors. In his opening remarks at the trial Brigadier General Telford Taylor, the American Chief of Council, noted: 'To kill, to maim, and to torture is criminal under all modern systems of law... yet these [physician] defendants, all of whom were fully able to comprehend the nature of their acts . . . are responsible for wholesale murder and unspeakably cruel tortures.' ${ }^{2}$

During the eight-month trial a detailed catalogue of medical experimentation was presented to the court. For example, at Dachau between 1942-1944 there was a series of experiments designed to examine aspects of aviation medicine, involving high-altitude experiments, the effects of freezing water baths and the enforced drinking of seawater. In Buchenwald and Ravensbrück throughout the war, a series of studies examined the simulation and treatment of battlefield injuries, such as exposure to mustard gas, phosphorus burns, bone transplantation, and sulfanilimide treatments. In Dachau, Buchenwald and Sachsenhausen during 1941-1945 there were a variety of infectious disease studies involving the deliberate infection of inmates with malaria, epidemic jaundice and typhus. Finally, in Auschwitz, Buchenwald and Ravensbrück there were a number of eugenic and lethal experiments involving sterilization and poisoned bullets. Similar, though less widely acknowledged, were the medical experiments performed in Japanese facilities during the Second World War. ${ }^{3}$

Nuremberg may have been the first major public exposition of how doctors can become instruments in unethical medical experimentation, but it is tragically not the last, nor regrettably the most recent.

During the Doctors' Trial in Nuremberg the defendants cited similar forms of human experimentation that had taken place in the USA. ${ }^{4}$ Names were named and details listed, but little note was taken by the American

Clinical Trials Unit, Glasgow Royal Infirmary, Glasgow G4 OSF, Scotland, UK

E-mail: Allan.Gaw@ctunit.co.uk prosecutors. Indeed the medical representative of the American Medical Association present at the trial, Andrew C. Ivy, stated that no American prisoner had ever been experimented on against his will. ${ }^{5}$ However, despite their heinous crimes against humanity, on this point the defendants were correct - and Ivy was wrong. The USA before, during and after the war was the host to a series of medical experiments that bore some striking similarities. Furthermore, although the 10 principles of ethical research that became known as the Nuremberg Code were drafted by the American team in Germany, it is notable that the Code was never taken to heart by American physicians, who preferred to view the document as applying not to them, but to the barbaric physicians in Nazi Germany. ${ }^{5}$

Then, as now, a utilitarian approach to biomedical research was commonly upheld as justification. 'This is done for the greater good' possibly thought the New York team that from 1963 deliberately infected the mentally retarded with hepatitis at Willowbrook, an institution on Staten Island, so that experimental vaccines could be tested. ${ }^{6}$ The 'benefit to society' may have been the touchstone of the Tuskegee investigators who between 1932 and 1972 followed a group of poor black Alabama farm workers to learn about the natural history of syphilis. ${ }^{7}$ In the process, and to avoid disruption of their experiment, they denied the men the benefits of penicillin therapy and subjected them to various investigations including regular lumbar punctures, which they passed off as treatments for so-called 'bad blood'. The 'advance of science' may have been the vision of those at the Jewish Chronic Disease Hospital in Brooklyn, who in the early 1960s injected live cancer cells into elderly debilitated cancer patients without their consent. ${ }^{8}$ These abuses of human research ethics were brought to light often not by our own colleagues, but by the media. ${ }^{9}$

\section{FINDING REASONS}

We must now condemn the actions of our professional colleagues in past decades for not only were their actions grossly unethical by our 21 st century standards, they were also incomprehensible even by their own codes of conduct at the time.

Even the doctors working in Buchenwald and Dachau had sworn the Hippocratic oath. How had they equated 
those ancient words, which define medicine as a profession, with their actions? How had the weight of the words 'first do no harm' been balanced as they subjected inmates to poisoning, deliberate infections, burns and freezing temperatures to the point of death?

Central to this enigma is the appreciation that many of those involved in such medical experimentation did not view their subjects as equals. At Nuremberg, Telford Taylor remarked that, 'To their murderers, these wretched people were not individuals at all'. ${ }^{2}$ With regard to the Tuskegee syphilis experiment, the Los Angeles Times noted that the US Public Health Service had persuaded hundreds of black men to become 'human guinea pigs', and then qualified that statement by saying: 'Well, perhaps not quite that, because the doctors obviously did not regard their subjects as completely human' ${ }^{10}$

Once this fundamental lack of respect is appreciated much of what followed in the death camps of Germany and Japan, and on the death campuses of many universities, as well as the wards of orphanages and mental institutions in the USA and elsewhere can be understood, if not condoned.

\section{WHAT WOULD WE HAVE DONE?}

We must condemn them, but perhaps it is all too easy to forget the circumstances. Of course there were evil masterminds at work in the camps, but the day-to-day conduct of these experiments was for the most part carried out by ordinary doctors. Furthermore, Tuskegee, Willowbrook and their like were carried out by doctors who genuinely believed they were doing good. Let us pause and ask the unthinkable. Had we been junior, or even not so junior doctors, working under Waldemar Hoven the Chief Physician in Buchenwald, or Shiro Ishii at the infamous Japanese Unit 731 in the 1940s, or indeed one of the resident physicians in that Brooklyn oncology ward or a staff doctor at Willowbrook in the 1960s, what would we have done? Would we have been swept along by our senior colleagues; would we have felt we were conducting valuable research on subjects who may not have given their consent, but who in any case had been sentenced to death either by the authorities or by nature itself? Or would we have simply feared for our careers, or even our own lives - seeing the situation in monochrome clarity - them or us?

It is romantic to think that we would have behaved differently, and I am sure some of us would have. But, I am equally sure that many of us would not. Given a set of extreme circumstances, or even a plausible set of orders from our superiors, it is not inconceivable that principles are abandoned, and replaced by a set of expedients that permit almost anything imaginable to be done in the name of science, or at least in the name of self-preservation. The in Nazi Germany, captured American airmen in Japan, or the mentally ill in a New York hospital, is what becomes important. If we operate in a context where such groups are not regarded as our equals, and where they have effectively forfeited their human rights, would we be willing to treat them differently? Of course we would say 'no' from our current perspective: all men and women and children are created equal. None should serve as the repositories of our test reagents, or as the tissue cultures for our incurable diseases. But, the reality is so often different. We are still utilitarian, because many of us do believe that the greatest good is served by the sacrifice of the rights of the few. During the Second World War it did not seem in the slightest improper that inmates of State Penitentiaries, including conscientious objectors, should be seen as reasonable experimental material. After all, many thousands of others were sacrificing their life and liberty in the European theatres of war. If another world war were to rage around us would our standards change? If our society and our way of life were threatened would we be willing to revisit the paths of our colleagues in Auschwitz?

Extreme circumstances seem to be the common thread that binds many of these abuses of medical ethics, and war is a major contributor. Many of the abuses of patients in wartime America were justified as attempts to help the troops, and who at the time could reasonably counter that argument? War also brings with it an enemy and an underclass. Grounded American airmen in Japan would be executed so where was the moral wrong in using them first as teaching aids for trainee surgeons, with or without anaesthetics. Jews and gypsies and homosexuals were earmarked for extermination in Nazi Germany, but why should they die in vain? What is worse: the act of extermination or the utilitarian approach to their terminal lives? Given the complete futility of saving these individuals, and their dehumanization in our eyes by years of propaganda, how many of us could have been persuaded that some greater good may come of participating in such research? These are disturbing and uncomfortable questions that are useful to ask, but deeply disconcerting to answer.

\section{PRESENT DAY}

We may console ourselves that the extreme circumstances, which may have brought about these atrocities, could not happen again. We may also distance ourselves from these events and shield ourselves behind a wall of ethical codes that have been designed to protect our patients from ourselves. We can conclude that this is nothing more than a history lesson, and the questions posed are little more than ethical exercises. Would that this were true. Alleged accounts of medical experimentation without consent against Iraqi Kurds by the Saddam regime were reported 
to the UN in $1998 .{ }^{11}$ And, even in the last few months physician assisted interrogation and torture have been alleged at the US military prisons in Abu Ghraib in Iraq and Guantanamo Bay in Cuba. ${ }^{12-15}$ Such incidents carry the legacy of Nuremberg, but have not been prevented by the Nuremberg Code. Nor have they been prevented by the 1964 Declaration of Helsinki, nor the 1997 Good Clinical Practice guidelines for the conduct of clinical trials, nor even the Hippocratic oath. The Geneva Conventions, designed to protect prisoners of war, also have no real power to protect especially when they are openly and formally dismissed as they were in February 2002, when the US president declared that they would not apply to 'enemy combatants' jailed at Guantanamo Bay. ${ }^{16}$

Codes of ethics exist to protect patients, but these are rarely read by dictators or by doctors who regard themselves as above the law. If acknowledged at all these codes may be disregarded in what are perceived as special circumstances, or because the patients are 'not entirely human'. As you read this, somewhere in the world a doctor is willingly or unwillingly involved in unethical medical research. Patients are being manipulated, incised, infected and treated against their will or without full knowledge of the procedures. The concept of consent should protect patients from doctors but the solution goes beyond consent. At the core of this activity is a basic disregard and lack of respect for the equality and humanity of mankind. Without such respect anything is possible.

That prisoners should not be used in medical research was implicit in the Nuremberg Code, but was not fully adopted by the USA until $1976 .{ }^{17}$ Despite the history of abuses and the apparently clear-cut ethical case for not using prisoners a recent call was made to re-examine this question and re-open the penitentiary doors to medical researchers. ${ }^{18}$

\section{CONCLUSION}

The obligations of the medical and paramedical professions in the conduct of biomedical research have never been clearer. Nor has our dishonourable history ever been more transparent. While clinical training now incorporates medical ethics and some elements of medical history, an awareness of the potential for atrocity should be a key element of all medical education. Sometimes in extreme circumstances; sometimes because of an imperceptible erosion of conscience, the past can happen again.

Competing interests None.

\section{REFERENCES}

1 Anonymous. The brutality of Nazi physicians [Editorial]. JAMA 1946; 132:714

2 United States v Karl Brandt et al. Trials Of War Criminals (T. Taylor, opening statement of the prosecution). Washington DC: Government Printing Office, 1949

3 Kristof, ND. Japan confronting gruesome war atrocity. New York Times, 17 March 1995

4 United States v Karl Brandt et al. Trials Of War Criminals. Washington DC: Government Printing Office, 1949:9114-228

5 Hornblum AM. They were cheap and available: prisoners as research subjects in twentieth century America. BMJ 1997;315: 1437-41

6 Moreno JD, Lederer SE. Revising the history of cold war research ethics. Kennedy Inst Ethics J 1996;6:223-38

7 US Public Health Service. Final Report Of The Tuskegee Syphilis Study Ad Hoc Advisory Panel. Washington DC: US Department of Health, Education, and Welfare, Public Health Service, 1973

8 Beecher HK. Ethics and clinical research. $N$ Engl J Med 1966;274: 1354-60

9 Heller J. Syphillis victims in U.S. study went untreated for 40 years. New York Times 26 July 1972

10 Brown, P. Perspectives in Medical Sociology, 2nd edn. Prospect Heights: Waveland Press, 1996

11 Moreno JD. Remember Saddam's human guinea pigs. Am J Bioethics 2003;3:1-2

12 Miles SH. Abu Ghraib: its legacy for military medicine. Lancet 2004; 364:725-9

13 Lewis NA. Red Cross finds detainee abuse in Guantanamo. New York Times, 30 November 2004

14 Leonnig CD. Further detainee abuse alleged. Washington Post, 26 December 2004

15 Bloche MG, Marks JH. Doctors and interrogators at Guantanamo Bay. N Engl J Med 2005;353:6-8

16 Memorandum for the president: humane treatment of al Qaeda and Taliban detainees. In: Greenberg KJ, Dratel JL, eds. The Torture Papers: The Road To Abu Ghraib. New York: Cambridge University Press, 2005: 134-5

17 Government to ban medical research on federal inmates. New York Times, 2 March 1976

18 Pasquerella L. Confining choices: should inmates' participation in research be limited? Theoret Med Bioethics 2002;23:519-36 